\title{
Polarised bovine endometrial epithelial cells vectorially secrete prostaglandins and chemotactic factors under physiological and pathological conditions
}

\author{
Siân B MacKintosh ${ }^{1,2}$, Hans-Joachim Schuberth ${ }^{3}$, Laura L Healy ${ }^{1}$ and I Martin Sheldon ${ }^{1}$ \\ ${ }^{1}$ School of Medicine, College of Medicine, Institute of Life Science, Swansea University, Singleton Park, Swansea SA2 \\ $8 P P, U K,{ }^{2}$ Department of Veterinary Clinical Sciences, Royal Veterinary College, Royal College Street, London NW1 \\ OTU, UK and ${ }^{3}$ University of Veterinary Medicine, Bischofsholer Damm 15, D-30173 Hannover, Germany
}

Correspondence should be addressed to S B MacKintosh at School of Medicine, College of Medicine, Institute of Life Science, Swansea University; Email: sianbethanp@gmail.com

\begin{abstract}
Epithelial cells of the endometrium secrete prostaglandins to regulate the bovine oestrous cycle and form a functional barrier to microbes. However, bacterial infection of the endometrium commonly causes infertility in dairy cattle by disrupting endometrial physiology. Epithelial cell cultures are used to study the mechanisms of physiology and pathology, but 2D cultures may not reflect the 3D complexity of the epithelium. In this study, a polarised epithelial cell transwell culture was developed, using transepithelial resistance (TER), to monitor epithelial integrity. Polarised epithelial cells were treated with oxytocin and arachidonic acid to test physiological function and with lipopolysaccharide (LPS) to mimic bacterial infection. Supernatants were analysed for prostaglandin $E_{2}$ (PGE), prostaglandin $F_{2 \alpha}$, the chemokine interleukin-8 (IL8) and the ability of supernatants to induce neutrophil migration. Confluent epithelial cells established polarity when TER was $>1800 \Omega \mathrm{cm}^{2}$ and predominantly released prostaglandins basolaterally. In contrast, IL8 from epithelial cells accumulated apically and the supernatants were highly chemotactic for neutrophils. The striking exception was when the epithelial cells were treated with LPS in the apical or basolateral compartment independently, which led to the release of IL8 towards the treated compartment. Although stromal cells also accumulated PGE and IL8 in response to treatment, co-culture of stromal cells in the well below polarised epithelial cells did not influence cellular responses. In conclusion, polarised endometrial epithelial cells vectorially released prostaglandins and chemokines to reflect their respective mechanistic roles in physiology and pathology.

Reproduction (2013) 145 57-72
\end{abstract}

\section{Introduction}

The endometrium comprises an epithelium overlaying a stroma containing mostly stromal cells but also endothelial cells and haematopoietic cells, including neutrophils, macrophages and T cells (Cobb \& Watson 1995). The epithelial cells of the bovine endometrium release prostaglandins, which have key physiological roles including the regulation of the oestrous cycle. However, the physiological function of the epithelium is commonly disrupted by bacterial infection (Sheldon et al. 2009). Bacterial infections of the endometrium are particularly common in post partum dairy cattle, leading to disease in $\sim 40 \%$ of animals, lower milk yields and infertility, with an associated cost of $\$ 600$ million per annum and $€ 1.4$ billion per annum within the USA and European Union respectively (Sheldon et al. 2009). Insights into the cellular function of bovine endometrial epithelial and stromal cells have been gained using 2D monocultures (Fortier et al. 1988, Herath et al. 2006). However, columnar epithelial cells have a 3D structure in vivo with a distinct apical vs basolateral polarity maintained by tight junctions, which are key to their barrier function (Wira et al. 2005, Giepmans \& van Ijzendoorn 2009). Thus, culture of polarised epithelial cells in 3D may be more relevant for studying cellular responses than unpolarised cells in 2D culture. Furthermore, epithelial and stromal cells commonly interact and so co-cultures may also be important to study the mechanisms of tissue function (Donjacour \& Cunha 1991). For example, murine and human endometrial epithelial proliferation is mediated by stromal cell responses to $17 \beta$-oestradiol via insulin-like growth factor 1 (Cooke et al. 1997, Pierro et al. 2001, Zhu \& Pollard 2007). Similarly, release of hepatocyte growth factor 1 from stromal cells increases polarised epithelial cell tight junction function and epithelial integrity, as determined by increased transepithelial resistance (TER; Grant-Tschudy \& Wira 2005b). Tight junctions are formed by claudin and occludin anchored to the actin cytoskeleton by zona occludens (ZO) proteins such as 
ZO1, and these junctions separate the apical and basolateral compartments of epithelia (Itoh et al. 1999, Tsukita et al. 2001). Regulation of tight junctions is important for the function of epithelia under physiological and pathological conditions (Balda et al. 1992, Matter et al. 2005). A bovine caruncular cell line (BCEC-1) established confluence when TER was $600-1600 \Omega \mathrm{cm}^{2}$, depending on the coating matrix of the insert (Bridger et al. 2007), and the presence of stromal cells was essential for the formation of tight junctions in cultured bovine endometrial epithelial cells (Ulbrich et al. 2011). However, the impact of epithelial cell polarisation on the mechanisms of bovine endometrial physiology or pathology is less well established.

The polarised epithelium is a key component of the mucosal barrier to pathogens invading the endometrium. Escherichia coli are the first bacteria commonly isolated during post partum infection of the endometrium in cattle (Williams et al. 2005, Sheldon et al. 2009). In addition to their barrier function, bovine endometrial cells have roles in innate immunity and anti-microbial defence of the endometrium. Epithelial and stromal cells express Toll-like receptors (TLRs) such as TLR4, which binds the lipopolysaccharide (LPS) of $E$. coli, stimulating the cellular release of prostaglandins, cytokines and chemokines that coordinate the immune response (Herath et al. 2006, Davies et al. 2008). Treatment of epithelial cells with LPS stimulates the release of luteoprotective prostaglandin $E_{2}$ (PGE) instead of the expected release of luteolytic prostaglandin $F_{2 \alpha}$ (PGF) under physiological conditions, regulated by oxytocin (OT; Herath et al. 2009). Stromal cells mainly produce PGE in response to LPS or in response to OT plus arachidonic acid (AA), the substrate for prostaglandin synthesis (Herath et al. 2006, 2009). In one study, bovine endometrial epithelial cells treated with OT had predominantly basolateral secretion of PGF but not PGE (Asselin et al. 1996), but the effect of LPS was not explored. Basolateral release of PGF by polarised endometrial epithelial cells has also been identified in other species, including the mouse, rat and pig (Jacobs et al. 1990, Braileanu et al. 2000). Interestingly, phorbol 12-myristate 13-acetate applied to only the basolateral surface of porcine epithelial cells stimulated a greater fold increase in basolateral PGF compared with treating either the apical surface only or both the apical and the basolateral epithelial surfaces (Braileanu et al. 2000). Bovine endometrial epithelial and stromal cells in 2D culture secrete cytokines such as interleukin-6 (IL6) and chemokines, such as IL8, in response to LPS (Herath et al. 2006, Davies et al. 2008). Polarised epithelial cells from the human endometrium predominantly release IL6, IL8 and granulocyte-macrophage colony stimulating factor apically (Fahey et al. 2005), which may help direct immune cells to the uterine lumen during infection. Bovine endometritis is associated with an influx of neutrophils into the tissue; IL 8 mRNA is more abundant in the endometrium during uterine disease; and infusion of the chemokine IL8 into the uterus attracts neutrophils (Caswell et al. 1999, Zerbe et al. 2003, Fischer et al. 2010). However, it is not clear whether bovine endometrial cells vectorially secrete prostaglandins or chemokines in response to LPS.

This study aimed to test the hypothesis that endometrial epithelial cells vectorially release prostaglandins and IL8 and that the supernatants induce neutrophil migration in vitro. To test this hypothesis, the first objective was to develop a model of polarised endometrial epithelial cells using primary bovine endometrial cells. The second objective was to use the model to explore the vectorial release of PGF, PGE and IL8 when the epithelial cells were cultured alone or co-cultured with stromal cells. A physiological scenario for evaluating the polarised cell responses was created by treating the cells with OT and AA, while mechanistic insights into endometrial pathology were tested using LPS from E. coli.

\section{Results}

\section{A model for polarised epithelial cells co-cultured with stromal cells was developed}

Epithelial and stromal cell proliferation on a Thin Coat of Matrigel was similar to that of cells cultured on a plastic culture well, but proliferation was reduced following culture on Matrigel prepared as a Thin Gel or when cells were embedded within a Thick Gel $(P<0.05$, Fig. $1 \mathrm{~A})$. Epithelial cells cultured on transwell inserts with a thin coat of Matrigel had a rapid increase in TER after 2 days of culture, which became stabilised once TER was $>1800 \Omega \mathrm{cm}^{2}$ on day 6 of culture (Fig. 1B), representing epithelial confluence. The TER profile of cells seeded on Millipore and Greiner transwell was similar (Fig. 1C). The TER of cells seeded on Corning and BD Falcon transwells was less than cells seeded on Millipore or Greiner transwells on day 6 and Nunc transwells failed to establish TER $>70 \Omega \mathrm{cm}^{2}(P<0.05$, Fig. 1C). Epithelial cells seeded at a density of $3 \times 10^{5}$ cells $/ \mathrm{ml}$ reached the TER threshold earliest on day 4 , and co-culture with stromal cells at the two seeding densities did not increase TER (Fig. 1D and E). Irrespective of seeding density, stromal cells established $100 \%$ confluence by day 3 , and cells seeded at $1 \times 10^{5}$ cells $/ \mathrm{ml}$ were ready for cell treatment on day 2 (Fig. 1F). Histological examination showed that the epithelial cells were polarised and had distinct apical bars between neighbouring cells (Fig. 1G), which corresponded with the expression of the tight junction-associated protein ZO1 (Fig. 1H). Polarised epithelial cells expressed the epithelial protein cytokeratin (Fig. 1H).

Based on these results, future transwell cultures were prepared using Millipore transwell inserts coated with a thin coat of Matrigel and seeded with epithelial cells at a density of $3 \times 10^{5}$ cells $/ \mathrm{ml}$. The TER threshold for 
A

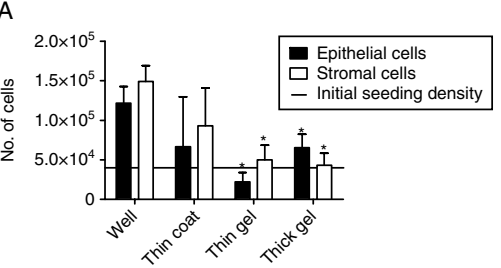

B

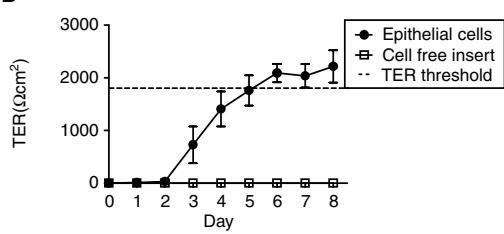

C

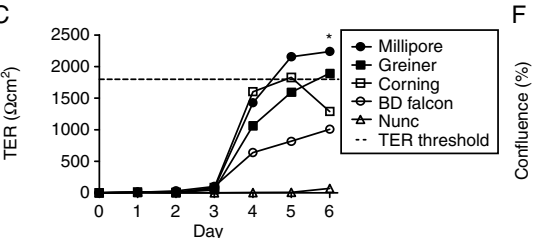

G

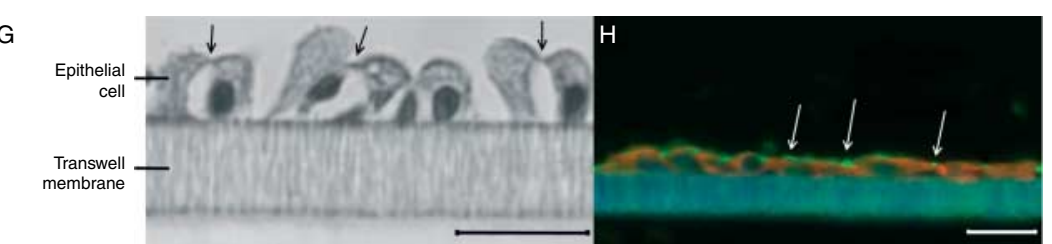

D

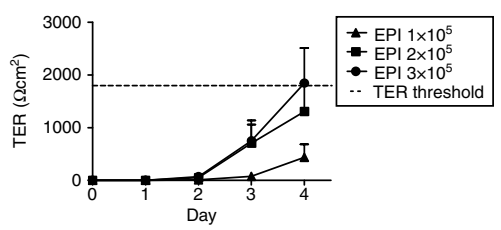

E

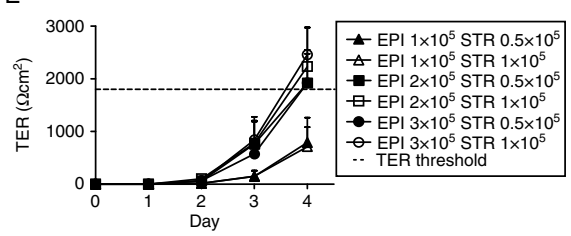

$\mathrm{F}$

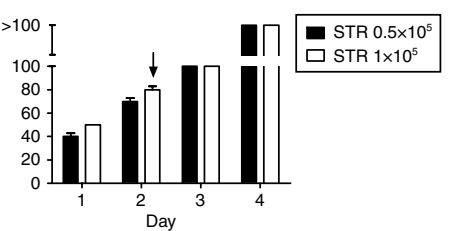

Figure 1 Establishment of a model of polarised epithelial cells co-cultured with stromal cells. (A) Growth of epithelial and stromal cells ( $n=3$ uteri) on untreated culture wells (Well) or wells coated with Matrigel prepared as a Thin Coat, Thin Gel or Thick Gel. The number of cells on Matrigel coatings differ from the uncoated 'Well', within cell type, ${ }^{*} P<0.05$. (B) TER of epithelial cells grown as monocultures on transwell inserts compared with cell-free inserts. The horizontal line indicates the TER threshold for confluence ( $n=150$ inserts, $n=12$ uteri). (C) TER profiles of epithelial cells grown on a range of transwell insert brands. Data are shown without S.E.M. for visual clarity, mean S.E.M. was $263.9 \pm 82.1 \Omega \mathrm{cm}^{2}$ and TER differed between brands on day 6, $P<0.05$. (D, E and F) Effect of epithelial and stromal cell seeding density on time taken to establish confluence for (D) epithelial monocultures, (E) co-culture or (F) stromal monoculture; desired confluence was obtained once TER was equal or greater than the TER threshold or where indicated by an arrow for stromal cells ( $n=3$ uteri). (G) H\&E staining of polarised epithelial cells on a transwell insert ( $n=3$ uteri). Arrows indicate apical cellular attachments between neighbouring cells, scalebar $=20 \mu \mathrm{m}$. (H) Cytokeratin (red) and ZO1 (green) expression by polarised epithelial cells on a transwell insert ( $n=3$ uteri). Arrows indicate punctuate expression of ZO1 at the apical-lateral membrane, scale bar $=20 \mu \mathrm{m}$.

epithelial confluence was set at $1800 \Omega \mathrm{cm}^{2}$. For co-culture studies, $1 \times 10^{5} \mathrm{cells} / \mathrm{ml}$ stromal cells were seeded once TER $>1500 \Omega \mathrm{cm}^{2}$, resulting in simultaneously confluent populations of both cell types.

\section{Polarised epithelial cells have vectorial release of PGE and PGF and maintain high TER following OT and/or $A A$ treatment}

Treatment of co-cultured epithelial and stromal cells or polarised epithelial monocultures with OT and/or AA increased PGE and PGF accumulation in both the apical and the basolateral supernatants $(P<0.001$, Fig. $2 \mathrm{~A}, \mathrm{~B}, \mathrm{C}$ and D). Basolateral accumulation of PGF and PGE was greater than apical accumulation by co-cultured cells and epithelial monocultures for all treatments $(P<0.05$, Fig. 2), except for the release of PGE by epithelial monocultures treated with AA alone where no significant difference was observed between the two compartments $(P<0.05$, Fig. 2C). Accumulation of
PGE or PGF did not differ significantly between epithelial monoculture and co-culture supernatants (Fig. 2). Stromal cell monocultures had increased accumulation of PGE in response to AA or OT + AA $(P<0.01)$ but not OT alone (stromal PGE accumulation: control: $3.5 \pm 0.5 \mathrm{ng} /$ $\mathrm{ml}$; AA treatment: $23.8 \pm 7.8 \mathrm{ng} / \mathrm{ml}$; OT+AA: 20.3 $\pm 8.2 \mathrm{ng} / \mathrm{ml}$; OT treatment: $3.6 \pm 1.1 \mathrm{ng} / \mathrm{ml})$. Stromal PGF production was $<3 \mathrm{ng} / \mathrm{ml}$ and did not differ significantly among treatments.

The TER of polarised epithelial cells in monoculture was similar to epithelial cells co-cultured with stroma (Supplementary Figure $1 \mathrm{~A}$ and $\mathrm{B}$, see section on supplementary data given at the end of this article). The TER of polarised epithelial cells alone or in co-culture did not differ significantly after 24-h treatment with OT and/or AA compared with TER before cell treatments (Supplementary Figure $1 \mathrm{~A}$ and $\mathrm{B}$ ). Also, the number of epithelial and stromal cells did not differ significantly among untreated cells and cells treated with OT and/or AA for $24 \mathrm{~h}$ (Supplementary Figure 1C and D). 
A

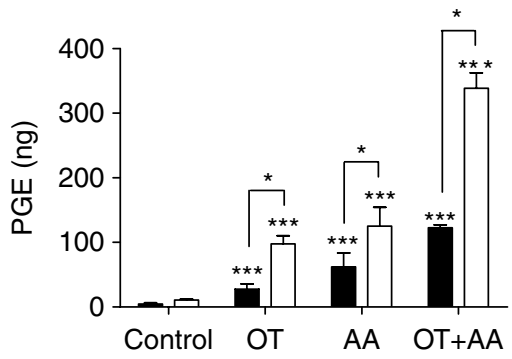

B

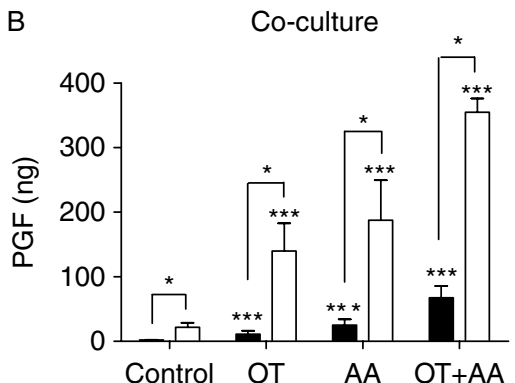

C Polarised epithelial cells

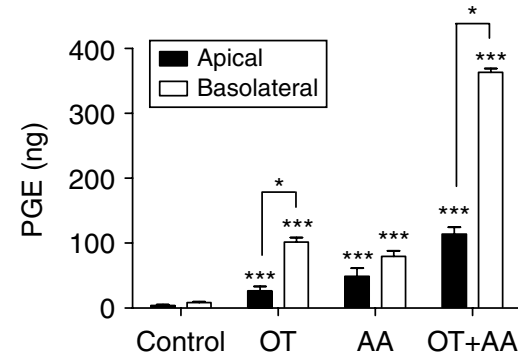

D

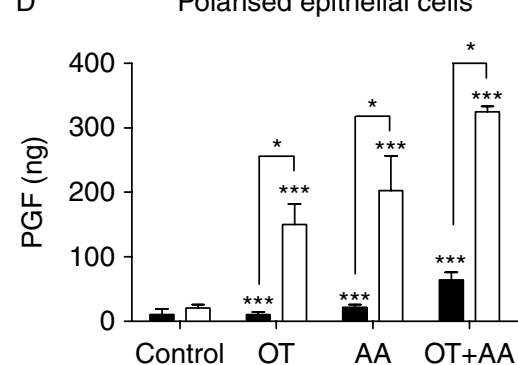

Figure 2 Accumulation of PGE and PGF by endometrial cells treated with OT and AA. (A and B) Polarised epithelial cells grown on transwell inserts were co-cultured with stromal cells in the well below or (C and D) polarised epithelial cells cultured alone. Endometrial cells ( $n=3$ uteri) were treated with control media, OT, AA or a combination of the two (OT+AA) for $24 \mathrm{~h}$. Accumulation (ng) of prostaglandin in the apical or basolateral supernatants is shown to account for differences in supernatant volume between compartments. Values differ between treatment and control, within culture type and compartment, $* * * P<0.001$, and between apical and basolateral supernatants, within treatment, ${ }^{*} P<0.05$.

\section{Endometrial cells show a concentration-dependent response to LPS, with polarised release of PGE, PGF and IL8 by epithelial cells}

Polarised epithelial cells in monoculture or co-cultures of epithelial and stromal cells had concentrationdependent increased accumulation of PGE, PGF and IL8 when treated with LPS for $24 \mathrm{~h}(P<0.01$, Fig. 3). Stromal monocultures produced PGE and IL8, but not PGF, in response to LPS treatment, $P<0.01$ (PGE, control: $12.6 \pm 3.1 \mathrm{ng} / \mathrm{ml}$ vs $1 \mu \mathrm{g} / \mathrm{ml}$ and LPS: 30.6 $\pm 9.5 \mathrm{ng} / \mathrm{ml}$; IL8, control: $0.3 \pm 0.3 \mathrm{pg} / \mathrm{ml}$ vs $1 \mu \mathrm{g} / \mathrm{ml}$ and LPS: $6.1 \pm 2.5 \mathrm{pg} / \mathrm{ml}$; PGF was always $<3 \mathrm{ng} / \mathrm{ml}$ ). Accumulation of PGE and PGF was always greater in the basolateral than in the apical compartment of polarised epithelial monoculture and co-cultures treated with LPS $(P<0.05$, Fig. 3). However, IL8 accumulation was greater in the apical compartment than the basolateral compartment following LPS treatment of epithelial monocultures or co-cultures $(P<0.05$, Fig. 3). Accumulation of PGE, PGF and IL8 did not differ significantly between epithelial monoculture and co-culture supernatants (Fig. 3). The ratio of PGE to PGF increased following LPS treatment compared with OT and/or AA treatment for both co-culture and polarised epithelial monocultures (The PGE to PGF ratio for polarised epithelial monoculture apical supernatants: $1.9 \pm 0.2$ and $6.4 \pm 1.5$ for OT + AA and LPS respectively $P<0.05$. The PGE to PGF ratio for co-culture apical supernatants: $2.1 \pm 0.5$ and $5.5 \pm 0.4$ for OT + AA and LPS respectively; $P<0.05$.).

The TER of polarised epithelial cells alone, or in co-culture, did not differ significantly after 24-h treatment with LPS compared with TER before cell treatment
(Supplementary Figure 2A and B, see section on supplementary data given at the end of this article). The TER was similar between epithelial cells cultured alone or when co-cultured with stroma (Supplementary Figure 2A and B). Compared with control, LPS did not alter the number of epithelial or stromal cells (Supplementary Figure 2C and D).

\section{Accumulation of IL8, but not prostaglandins, is directed to the site of LPS treatment in transwell culture}

To compare apical and basolateral responsiveness of polarised epithelial cells to LPS and to determine whether apical exposure of epithelial cells to LPS stimulated a stromal cell prostaglandin or IL8 response, transwell cultures were treated apically, basolaterally or in both compartments. Treatment of polarised epithelial monocultures with LPS induced PGE and PGF accumulation in both apical and basolateral compartments, irrespective of the site of LPS treatment $(P<0.05$, Fig. 4D and E). For co-cultured cells, accumulation of PGE was only significantly increased following LPS treatment of the basolateral compartment or both compartments $(P<0.05$, Fig. 4A), whereas PGF was increased in all compartments following any LPS treatment $(P<0.05$, Fig. 4B). The PGE and PGF was always preferentially accumulated in the basolateral compartment, for both epithelial monoculture and co-cultures $(P<0.05$, Fig. 4A, B, D and E). Accumulation of PGE by co-cultures treated with LPS was greater than that of epithelial monocultures $(P<0.05$, Fig. $4 \mathrm{~A}$ and $\mathrm{D})$.

The accumulation of IL8 by both epithelial monocultures and co-cultures was also increased by LPS 
A

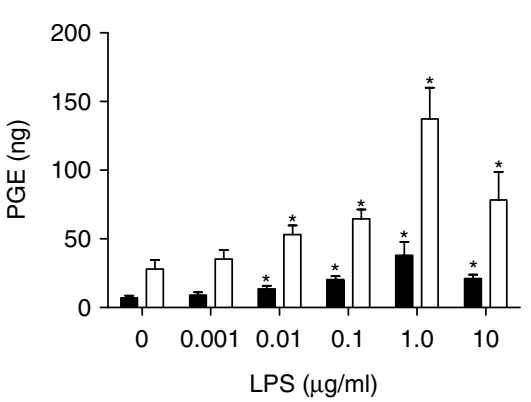

B

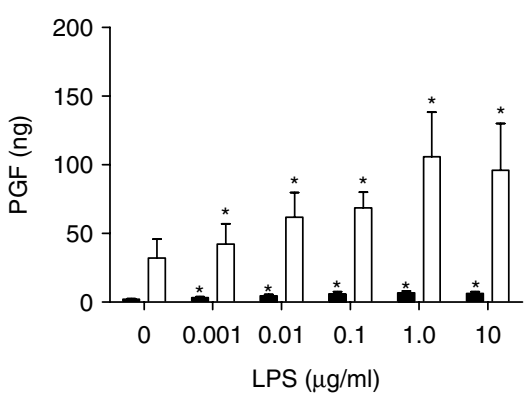

C

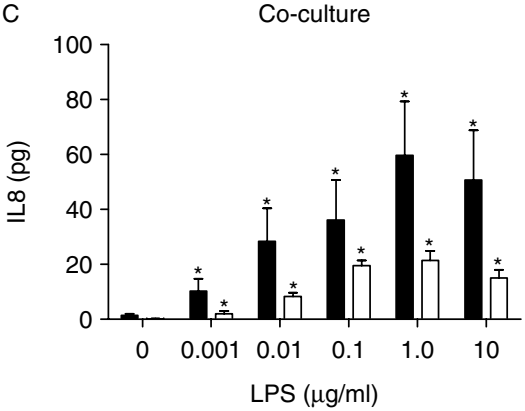

D

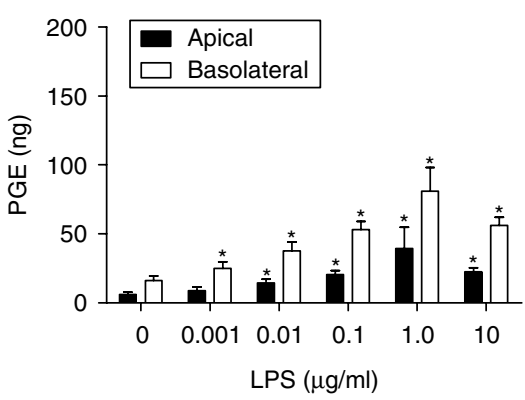

E

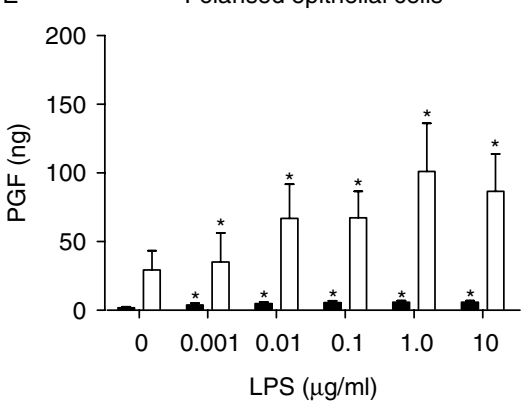

$\mathrm{F}$

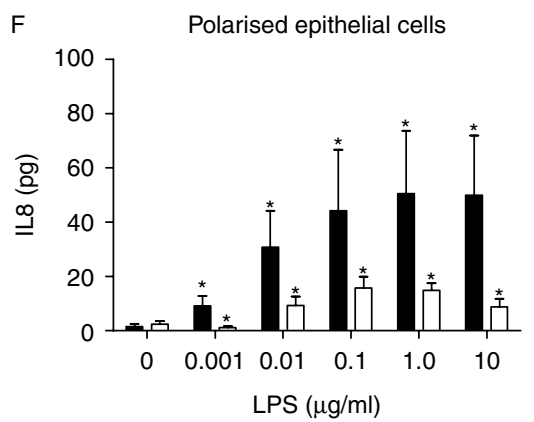

Figure 3 Effect of LPS on PGE, PGF and IL8 accumulation by endometrial cells. (A, B and C) Co-cultured epithelial and stromal cells or (D, E and F) polarised epithelial monocultures were treated in both the apical and the basolateral compartments of transwell cultures with LPS $(0-10 \mu \mathrm{g} / \mathrm{ml})$ for $24 \mathrm{~h}$. Accumulation of PGE, PGF (ng) and IL8 (pg) in the apical and basolateral supernatants is shown ( $n=3$ uteri), and values differ between control and LPS treatment, within compartment, ${ }^{*} P<0.05$. Basolateral accumulation of PGE and PGF was always greater than apical accumulation, $P<0.05$. IL8 was accumulated preferentially in the apical compartment, $P<0.05$. treatment, but unlike prostaglandin accumulation, the compartment with the greater accumulation of IL8 corresponded with the site of LPS treatment $(P<0.05$, Fig. 4C and F). Where LPS was applied to both compartments of polarised epithelial monocultures, the accumulation of IL8 in each compartment reflected that when LPS was applied independently, but with predominantly apical IL8 accumulation (Fig. 4F). The co-culture accumulation of IL8 in the basolateral compartment was greater than that of epithelial monoculture following basolateral, but not apical, LPS treatment ( $P<0.05$, Fig. $4 \mathrm{C}$ and $\mathrm{F})$.

Stromal monocultures accumulated more PGE and IL8, but not PGF, in response to LPS treatment (PGE accumulation: $33.7 \pm 5.1$ and $141.1 \pm 42.1$ for control and LPS $(1 \mu \mathrm{g} / \mathrm{ml})$ respectively; IL8 accumulation: 4.7 \pm 2.9 and $52.1 \pm 18.7 \mathrm{pg} / \mathrm{ml}$ for control and LPS $(1 \mu \mathrm{g} / \mathrm{ml})$ respectively, $P<0.05)$. Treatment with LPS did not significantly affect the number of cells in any of the cultures, irrespective of the site of treatment $(P>0.6$; Supplementary Figure 3, see section on supplementary data given at the end of this article).

\section{Endometrial cell supernatants induce neutrophil chemotaxis in vitro}

Bovine neutrophils had maximal migration rates $(94 \pm 0.7$ and $92 \pm 1.7 \%$ ) towards $100 \mathrm{ng} / \mathrm{ml}$ recombinant human IL8 (rhIL8) diluted in either RPMI 1640 or respectively compared with migration to RPMI 1640 or endometrial culture media alone $(P<0.05$, Fig. 5A). Migration to rhIL8 and recombinant bovine IL8 (rbIL8) was identical (Supplementary Figure 4, see section on supplementary data given at the end of this article). The presence of LPS diluted in endometrial culture media did not induce neutrophil migration compared with culture media alone (Fig. 5A). Neutrophil migration rates to supernatants from endometrial cells that had not been treated with LPS were greater than migration rates to unconditioned culture media $(P<0.001$, Fig. 5). Supernatants from LPS-treated endometrial cells further increased neutrophil migration rates, irrespective of the endometrial culture type ( $P<0.001$, Fig. 5B, C and D), but migration was not LPS dose dependent (Fig. 5). Chemotaxis to the apical supernatants was greater than 
A

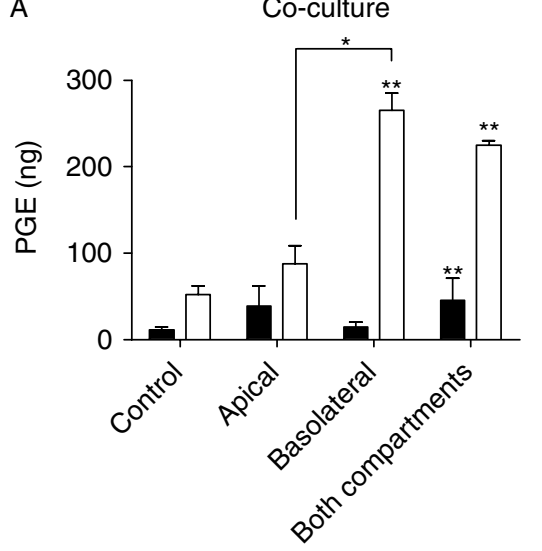

Site of LPS application

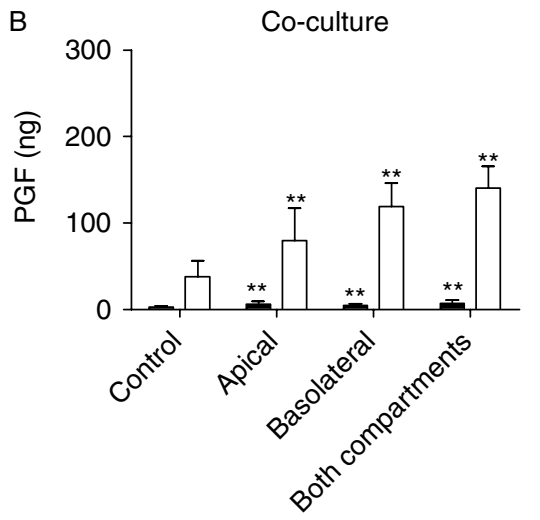

Site of LPS application

C

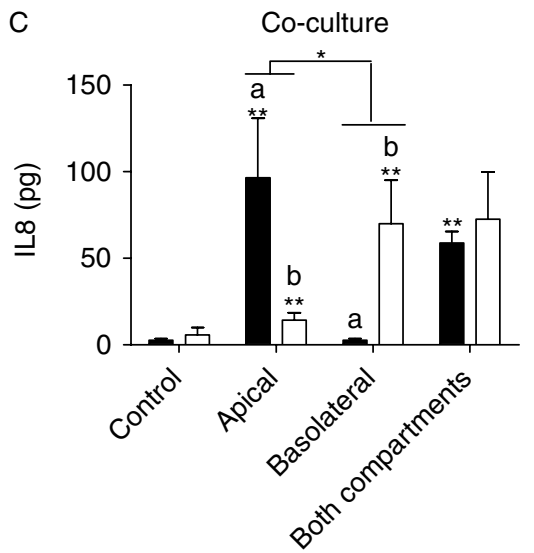

Site of LPS application

D Polarised epithelial cells

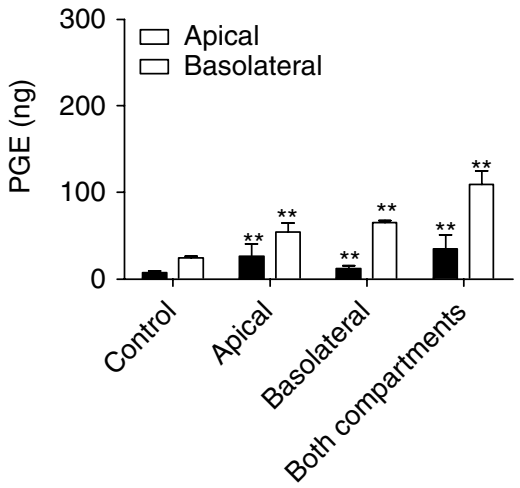

Site of LPS application

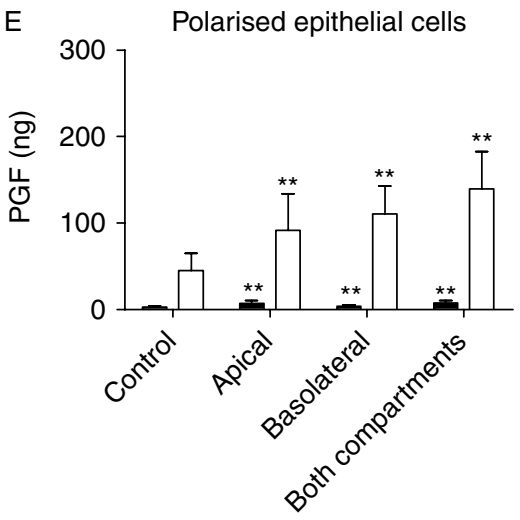

Site of LPS application

$\mathrm{F}$

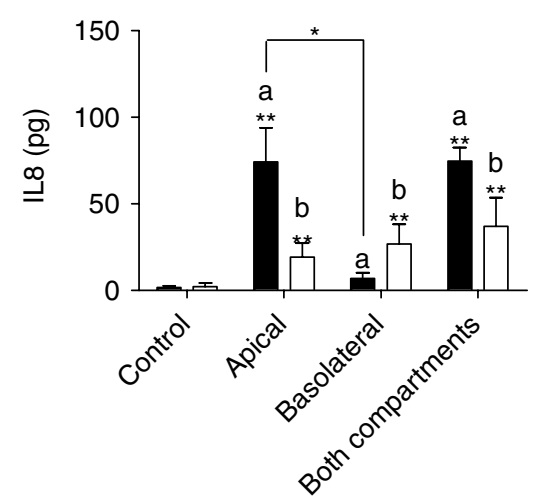

Site of LPS application
Figure 4 Effect of site of LPS treatment on PGE, PGF and IL8 accumulation. (A, B and C) Co-cultured epithelial and stromal cells or (D, E and F) polarised epithelial monocultures were treated with $1 \mu \mathrm{g} / \mathrm{ml}$ LPS in the apical compartment, basolateral compartment or both compartments of transwell cultures for $24 \mathrm{~h}$. Control media were applied to the untreated compartment. Accumulation of PGE, PGF (ng) or IL8 (pg) in the apical supernatants (closed square) and basolateral supernatants (open square) is shown ( $n=3$ uteri). Values between LPS treatment and control, $* * P<0.05$, and between site of LPS treatment, $* P<0.05$. Basolateral accumulation of PGE and PGF was always greater than apical accumulation, $P<0.05$. There was vectorial accumulation of IL8, within treatment, ${ }^{\mathrm{a}, \mathrm{b}} \mathrm{P}<0.05$. migration to basolateral supernatants of polarised epithelial monocultures, but not co-culture supernatants $(P<0.001$, Fig. 5B and C).

The migration rate of neutrophils to $5 \mathrm{ng} / \mathrm{ml}$ rblL8 was $26 \pm 4.0 \%$ (Supplementary Figure 4). In contrast, the greatest observed accumulation of IL8 by endometrial cells treated with a LPS dose response was 0.06 $\pm 0.02 \mathrm{ng} / \mathrm{ml}$, where co-culture cells were treated with $1 \mu \mathrm{g} / \mathrm{ml} \mathrm{LPS} \mathrm{(Fig.} \mathrm{3);} \mathrm{yet} \mathrm{the} \mathrm{corresponding} \mathrm{endometrial}$ cell supernatant induced $90 \pm 1 \%$ neutrophil migration (Fig. 5). The addition of neutralising IL8 antibody inhibited the chemotaxis of neutrophils to $7.5 \mathrm{ng} / \mathrm{ml}$ rblL8 diluted in culture media $(P<0.05$, Fig. 6). The addition of anti-IL8 did not alter the migration to any LPS-treated endometrial supernatants, irrespective of the cell culture type or supernatant compartment (Fig. 6), this was also true of supernatants from endometrial cells not treated with LPS (data not shown). 


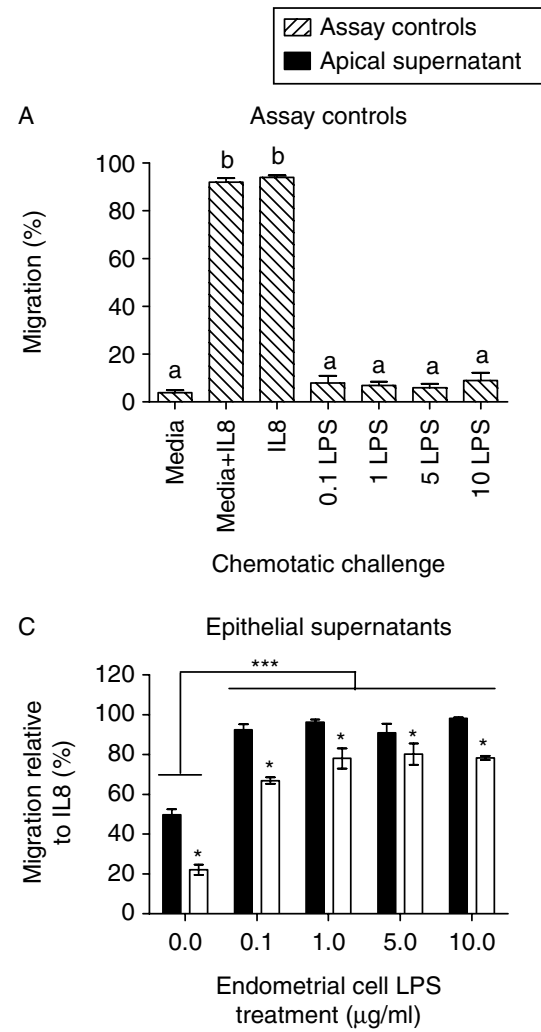

\section{Discussion}

This study developed a defined system to study polarised endometrial epithelial cells. Epithelial cells in transwell monoculture expressed the tight junction protein ZO1, formed apical bars between neighbouring cells and had vectorial secretion of PGE, PGF and IL8 indicating establishment of an intact polarised epithelium and formation of functional tight junctions. The system was used to explore cellular responses to physiological or pathological stimuli. Interestingly, preferential accumulation of IL8, but not PGE or PGF, corresponded with the site of LPS treatment, which may indicate a directed IL8 response by polarised epithelial cells. The endometrial supernatants induced migration of bovine neutrophils in vitro, but IL8 was not solely responsible for this chemotaxis.

A system for studying bovine polarised endometrial epithelial cells, cultured alone or in the presence of stromal cells, has been relatively unexplored compared with similar models in the rodent and human (Jacobs et al. 1990, Arnold et al. 2001). Polarisation of epithelial cells enhances the ability to measure the specialised functions of this cell type, such as vectorial secretion of products and tight junction activity (Glasser et al. 1988, Fahey et al. 2005). The co-culture of endometrial epithelial and stromal cells from other species has been previously shown to modify certain cell responses, for example TER, epithelial cell proliferation and
Figure 5 Neutrophil migration to endometrial cell supernatants. (A) Neutrophil migration to assay controls: endometrial culture media (Media), endometrial culture media containing $100 \mathrm{ng} / \mathrm{ml}$ rhlL8 (Media + IL8), pure RPMI 1640 containing $100 \mathrm{ng} / \mathrm{ml}$ rhIL8 (IL8) or endometrial culture media containing $0.1,1,5$ or $10 \mu \mathrm{g} / \mathrm{ml}$ LPS (LPS). Columns with different superscript are significantly different, ${ }^{a, b} P<0.05$. (B, C and D) Neutrophil chemotaxis apical (closed square), basolateral (open square) or well (closed square) supernatants from (B) co-cultured epithelial and stromal cells, (C) polarised epithelial monocultures or (D) stromal monocultures treated with $0.1,1,5$ or $10 \mu \mathrm{g} / \mathrm{ml}$ LPS ( $n=1$ blood donor, $n=3$ uteri). Neutrophil migration to endometrial supernatants containing LPS was greater than LPS-free supernatants, ${ }^{* * *} P<0.001$. Migration to apical or basolateral supernatants differed, within LPS treatment and culture, ${ }^{*} P<0.05$. cytokine secretion (Arnold et al. 2001, Grant-Tschudy \& Wira 2005b). In this study, the first objective was to develop a suitable model of primary bovine polarised epithelial cells. The development process included

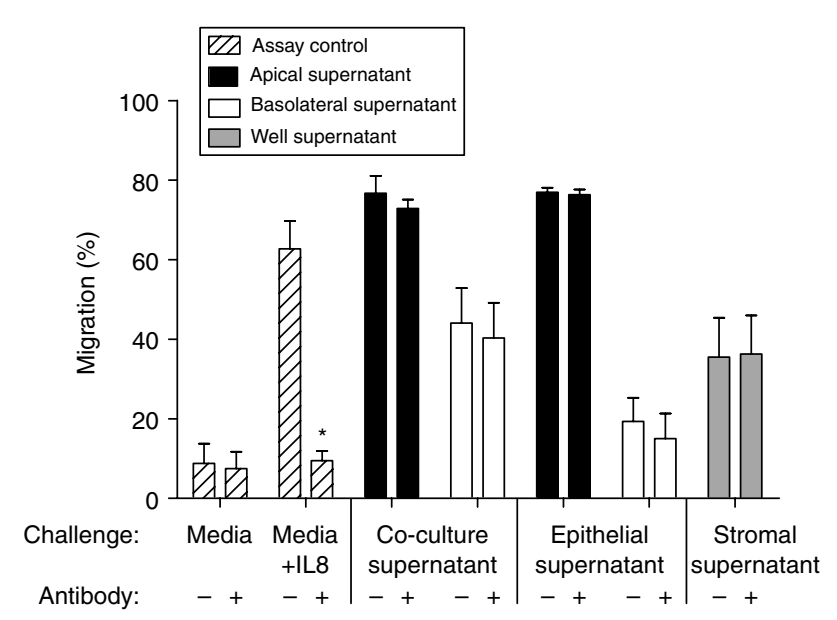

Figure 6 Inhibition of neutrophil migration using neutralising IL8 antibody. Anti-IL8 was added to inhibit neutrophil chemotaxis to supernatants from endometrial cell cultures treated for $24 \mathrm{~h}$ with $1 \mu \mathrm{g} / \mathrm{ml}$ LPS. Assay controls (hatched bars) included endometrial culture media alone, 'Media', or containing $7.5 \mathrm{ng} / \mathrm{ml}$ rbIL8, 'Media + IL8'. The effect of anti-IL8 was tested on apical supernatants (closed square), basolateral supernatants (open square) of polarised epithelial cells cultured alone (epithelial supernatant) or with stromal cells (co-culture), or the well of stromal monocultures (closed square). Addition of anti-IL8 reduced migration, $* P<0.05$. 
characterisation of TER, selection of transwell inserts and optimisation of Matrigel coating. As epithelial and stromal cells exhibit different growth rates, cell seeding density was also addressed to achieve simultaneously confluent epithelial and stromal cells for co-culture (Fortier et al. 1988).

The TER reflects both epithelial confluence and tight junction function (Tsukita et al. 2001, Fahey et al. 2005). The stabilised TER identified in this study after $\sim 5$ days of culture was comparable to a bovine caruncular epithelial cell line (Bridger et al. 2007). The finding that polarised endometrial epithelial monocultures can establish high TER is in agreement with reports for mouse endometrial cells (Grant \& Wira 2003, Grant-Tschudy \& Wira 2005b). In this study, co-culture of stromal and epithelial cells did not alter the TER, which is in contrast to previous reports of murine endometrial cells where the release of stromal-derived factors increased TER (Grant \& Wira 2003, Grant-Tschudy \& Wira 2005b). Tight junction formation by bovine epithelial monocultures is also in contrast to a previous report that demonstrated that tight junctions, imaged using electron microscopy, were only present when bovine endometrial epithelial cells were co-cultured with stromal cells in the well below (Ulbrich et al. 2011). However, the study by Ulbrich et al. (2011) used Nunc inserts, which were also tested in this study and were the only tested brand of transwell inserts that failed to establish high TER. The Nunc transwell was the only brand with a $0.2 \mu \mathrm{m}$ pore size and a non-hanging geometry, and this may account for a substantially lower TER if the current was being conducted through the feet of the Nunc transwell inserts but would not explain the absence of tight junction formation by monoculture epithelial cells in previous reports (Ulbrich et al. 2011). In this study, differences in TER of epithelial cells seeded on different brands of transwells were apparent, despite TER being adjusted for differences in the cell-free (blank) transwells and variations in transwell membrane area. This may indicate the importance of determining the TER profile of epithelial cells on a given brand of transwell insert before carrying out downstream experiments that would be reliant on TER measurements to indicate cell confluence and epithelial integrity. Millipore transwells were selected in this study as epithelial cells seeded on these inserts were the first to obtain the TER threshold and the hanging geometry allowed for seeding stromal cells in the well below for co-culture studies.

Matrigel has been widely used in other transwell culture models to coat transwell inserts in order to enhance epithelial cell attachment and differentiation (Schatz et al. 1990, Asselin et al. 1996, Ulbrich et al. 2011). The Matrigel coating of transwell inserts selected in this study was the Thin Coat, a non-gelled, thin extracellular protein coating of Matrigel, as this application of Matrigel resulted in cell proliferation similar to a standard uncoated culture well. In contrast, the use of a
Thin Gel with cells growing on top or cells embedded within a Thick Gel reduced proliferation. Human endometrial epithelial cells cultured on Matrigel have been previously shown to have increased proliferation compared with those cultured on plastic, whereas stromal proliferation was inhibited by Matrigel (Arnold et al. 2001). This result is perhaps unsurprising as Matrigel facilitates predominantly cellular differentiation, rather than proliferation (Kubota et al. 1988, Kleinman \& Martin 2005). In this study, culture of epithelial cells on a Thin Coat of Matrigel produced a polarised morphology of epithelial cells with high TER. This was matched by apical-lateral expression of the tight junction-associated protein, ZO1, which corresponded to apical-lateral bars adjoining neighbouring cells as viewed using haematoxylin and eosin staining indicating appropriate epithelial differentiation.

Using our culture model, PGE accumulation by polarised epithelial cells was greater than PGF accumulation. This is in contrast to previous reports for both bovine endometrial epithelial cells cultured on transwell inserts or as 2D monolayers, where OT stimulated accumulation of more PGF than PGE (Asselin et al. 1996, Herath et al. 2006). However, the OT responsiveness and expression of OT receptors of epithelial cells varies during the oestrous cycle in pregnant animals, with basal OT receptor expression in the mid-luteal phase, and greatest expression during the late luteal phase and oestrous cycle (Meyer et al. 1988, Asselin et al. 1996, Goff 2004, Waclawik et al. 2010). In this study, early luteal phase uteri were selected as the study was focussed on using a co-culture model to study aspects relating to the post partum disease, endometritis. Post partum uteri were not used for cell culture studies due to ubiquitous bacterial contamination of the post partum uterus (Sheldon et al. 2009) and the disruption of the endometrial epithelium following parturition (Wagner \& Hansel 1969, Chapwanya et al. 2009). Instead, early luteal phase uteri were selected as this stage of the cycle best mimics the steroid profile of post partum uteri (Cronin et al. 2012). In 2D cultures of bovine endometrial epithelial cells, the type of prostaglandin secreted was dependent on the cell treatment, with OT + AA stimulating predominantly PGF, but $E$. coli LPS stimulated predominantly PGE accumulation by epithelial cells (Herath et al. 2006, 2009). In agreement, in this study, LPS treatment increased the PGE to PGF ratio compared with OT and/or AA treatment. Prostaglandins are produced from the common precursor AA, which is liberated from cell membranes by phospholipase A2 (PLA2) enzymes. The type of prostaglandin produced may depend on the PLA2 enzyme that is stimulated, where the PLA2 group 6 enzyme is associated with PGF accumulation, and PLA2 group 4C enzyme is associated with PGE accumulation (Tithof et al. 2007). A predominant release of luteoprotective PGE following an $E$. coli infection of the uterus may mediate the 
prolonged luteal phases that are associated with bovine endometritis (Mateus et al. 2003, Herath et al. 2009).

In this study, stromal cell monocultures accumulated PGE in response to OT + AA or LPS, which supports the previous observations that while stromal cells do not express OT receptors, when supplied with AA, the cells produce PGE with little PGF (Fortier et al. 1988, Herath et al. 2006). In each experiment, both epithelial and stromal monocultures were tested to identify where an effect of co-culture had occurred, and thus, an additive or inhibitory effect of having two cell types in culture could be identified. While PGF would not be expected to result in an additive effect, as stromal cells produce little PGF, it was possible that PGE and IL8 accumulation by co-cultures could be increased compared with monoculture. However, in most cases, the accumulation of PGE, PGF and IL8 did not differ between polarised epithelial monocultures and co-cultures. The exception to this was seen in the experiment that tested the effect of site of LPS experiment, where co-cultures accumulated more PGE and IL8 than polarised epithelial monocultures following the addition of LPS to the basolateral compartment. Where an additive effect was observed, the stromal cells had a greater basal concentration of PGE and IL8 accumulation than in the other experiments in this study. Differences in basal accumulation of products may reflect biological variation between animals. The lack of an additive effect of co-culture may indicate that there is a greater rate of metabolism of secreted prostaglandin and IL8. In this study, metabolism of secreted products was not examined but requires further investigation to confirm whether this is the case.

Accumulation of PGE and PGF by polarised epithelial cells, cultured alone or co-cultured with stroma, was predominantly basolateral following either physiological or pathological treatment. This is in contrast to a previous report, where polarised bovine epithelial cells treated with OT had predominantly basolateral accumulation of PGF, but not PGE (Asselin et al. 1996). However, porcine endometrial epithelial cells and the bovine endometrial epithelial cell line, bEEL, reportedly have predominantly basolateral release of both PGE and PGF (Bowen et al. 1996, Lacroix-Pepin et al. 2011). Prostaglandins are charged anions that diffuse poorly across cell membranes, thus require facilitated transport by the prostaglandin transporter (PGT) and multidrug resistance-associated protein 4 (MRP4; Schuster 1998, Banu et al. 2003, Tithof et al. 2007, Lacroix-Pepin et al. 2011). In the bovine reproductive tract, $\mathrm{PGT}$ is predominantly, but not exclusively, localised to the basolateral membrane of endometrial epithelial cells, whereas stromal cells have diffuse membrane expression of PGT (Banu et al. 2003), and MRP4 appears to be specifically involved in the basolateral release of PGF and PGE by bEEL cells (Lacroix-Pepin et al. 2011). Basolateral release of prostaglandins may direct the prostaglandins towards the utero-ovarian plexus, which is necessary for efficient transport of prostaglandins from the uterus to the ovary in ruminants (Niswender et al. 2000, Banu et al. 2005). This hypothesis would appear to be supported by the in vivo observations that PGE and PGF are detectable in the utero-ovarian venous serum, but not the uterine lumen flushings, of ewes on days 13-17 of the oestrous cycle (Ellinwood et al. 1979), and inhibition of PGT within the utero-ovarian plexus prevented the transport of PGF from the uterine venous blood into the ovarian artery in the ewe (Lee et al. 2010).

Polarised epithelial cells also had vectorial accumulation of IL8 following LPS treatment, but unlike PGE and PGF, the release of IL8 was directed to the site of LPS treatment in the polarised epithelial monocultures, where apical LPS treatment caused predominantly apical IL8 release and vice versa for the basolateral compartment. Directed release of IL8 has been previously reported in human bronchial polarised epithelial cells (Chow et al. 2010, Kanoh et al. 2011). In this study, and in a previous report describing human bronchial epithelia (Kanoh et al. 2011), apical LPS treatment increased IL8 accumulation in the apical and basolateral compartment, whereas basolateral LPS treatment elevated only basolateral IL8 accumulation. This directed release may be limited to particular chemokines, as a report of bronchial epithelial IL6 accumulation (Chow et al. 2010) and prostaglandin release in this study were not influenced by the site of LPS treatment. It has been postulated that NF- $\kappa B$, p38 MAPK and ERK1/2 MAPK are involved in the polarised release of IL8 in respiratory tract epithelia (Chow et al. 2010). Binding of TLR4 causes the activation of these signalling molecules to cause transcription of the mRNA of cytokines, chemokines, including that of IL8 (Takeuchi \& Akira 2010, Kannaki et al. 2011, Cronin et al. 2012). Thus, the signalling molecules may be responsible for production of IL8 and there may be additional mechanism for the specific directed release of IL8 following LPS treatment. Where polarised epithelial cells were treated in both compartments with LPS, a predominantly apical IL8 accumulation was observed, which is in agreement with previous reports for human and murine endometrial epithelial cells (Shen et al. 2004, Fahey et al. 2005, Grant-Tschudy \& Wira 2005a, Soboll et al. 2006). It has been suggested that a predominantly apical release of IL8 may cause chemotaxis of neutrophils into the uterine lumen during an infection (Fahey et al. 2005). From this study, it appears that polarised epithelial cells have an even more sophisticated ability to direct IL8 release towards the site of infection, whether it occurs in the uterine lumen or the sub-luminal tissues.

The PGE and IL8 accumulation was similar between co-cultures or epithelial monocultures treated apically with LPS. So, exposure of the apical membrane of an intact epithelium to purified LPS does not appear to indirectly stimulate stromal cell production of PGE or 
IL8. It also seems unlikely that any apically applied LPS reaches the stromal cells where the epithelium is intact because stromal cells produced PGE and IL8 following direct exposure to LPS in this study and in previous reports (Herath et al. 2009, Sheldon et al. 2010). However, in vivo, the caruncular epithelium becomes at least partially denuded following parturition, allowing exposure of underlying stromal cells to LPS from the bacteria that colonise the post partum uterus (Archbald et al. 1972, Sheldon et al. 2009). These stromal cellderived inflammatory factors and chemokines may become important following a breach of the epithelium.

IL8 is a potent chemokine of neutrophils, and infusion of rhlL8 into the uterus of cows induces migration of neutrophils into uterine lumen (Caswell et al. 1999, Zerbe et al. 2003). The up-regulation of IL 8 mRNA in the endometrium is one of the most consistent features of endometritis (Fischer et al. 2010). In this study, endometrial cell supernatants induce neutrophil migration in vitro, and LPS treatment of endometrial epithelial and stromal cells increased both the release of IL8 and increased chemotactic potential of the cell supernatants. It was reported previously that untreated epithelial cell supernatants from healthy human endometrium had chemotactic potential, and LPS increased this effect (Shen et al. 2004). In this study, LPS was not chemotactic, in agreement with a previous report (Galligan \& Coomber 2000). While apical and basolateral supernatants from co-cultured endometrial cells induced similar migration, polarised epithelial apical supernatants induced greater neutrophil migration than basolateral supernatants. This corresponded with the predominantly apical release of IL8 by polarised epithelial cells observed when both the apical and the basolateral compartments are treated with LPS.

To fully elucidate whether IL8 was the key chemokine in the endometrial supernatants responsible for inducing neutrophil migration, the effect of a neutralising IL8 antibody was tested. This antibody was effective at inhibiting migration to a sub-maximal dose of recombinant bovine IL8, and endometrial supernatants were diluted 1:7 to ensure that the chemotaxis they induced was also sub-maximal. However, addition of the IL8 antibody did not reduce the migration of neutrophils to any endometrial supernatants, irrespective of culture type or LPS treatment. It was unexpected that IL8 antibody did not at least partially inhibit chemotaxis. Intriguingly, the measured amounts of IL8 in the bovine supernatants were far below the amounts of recombinant IL8 required to induce comparable chemotaxis in vitro. For example, where LPS-treated endometrial supernatants produced $<0.06 \mathrm{ng} / \mathrm{ml} \mathrm{IL8}$ and induced $>60 \%$ migration, $10 \mathrm{ng} / \mathrm{ml}$ rblL 8 was required to induce $55 \pm 4 \%$ neutrophil migration. Culture supernatants likely contain a variety of potential chemoattractants, and this will partly explain why IL8 antibody was ineffective in this study. Neutrophil migration to human endometrial cell supernatants could be partially reduced by addition of either IL8 or granulocyte-monocyte colony stimulating factor antibodies, and almost complete inhibition of migration was achieved when the antibodies were used in combination (Shen et al. 2004). As the neutralising IL8 antibody failed to block neutrophil chemotaxis to bovine endometrial supernatant in this study, further work is required to identify other potential chemotactic factors produced by bovine endometrial supernatants.

Another area for future consideration is the individual roles of luminal and glandular epithelial cells. The culture model described in this study used a heterogeneous population of luminal and glandular epithelial cells, a technique that has been widely used to study epithelial cell function (Asselin et al. 1996, Horn et al. 1998, Herath et al. 2009). However, there is evidence that luminal and glandular epithelial cells differ in their morphology and functionality (Zhang \& Davis 2000), and specific cultures of either luminal or glandular epithelial cells have been established for the rat (Jacobs et al. 1990), the pig (Braileanu et al. 2000, Waclawik et al. 2010) and guinea pig (Mahfoudi et al. 1991). Additionally, cell cultures of the superficial endometrial epithelium have been established in the cow (Thibodeaux et al. 1991). It would therefore be beneficial to test the separate responses of both luminal and glandular epithelial cells using the model described in this study.

In conclusion, a tractable model was developed to study primary bovine endometrial epithelial cells in their 3D polarised state. These epithelial cells had vectorial accumulation of PGE, PGF and IL8 and maintained TER following treatment with OT and/or AA or LPS. Strikingly, accumulation of IL8, but not PGE or PGF was directed towards the site of LPS treatment. These observations may reflect the respective roles of chemokines and prostaglandins in pathology and physiology of the endometrium.

\section{Materials and Methods}

\section{Isolation and culture of endometrial cells}

Uteri were collected from an abattoir from non-pregnant cattle (Bos taurus) under 30 months of age, immediately following slaughter, with approval of the Local Ethics Review Panel and the UK Food Standards Agency. Uteri of the early luteal phase (days 1-4 of oestrous cycle) were selected, based on ovarian morphology as described previously (Ireland et al. 1980). Early luteal phase uteri were selected as this stage of cycle best mimics the post partum steroid profile of the reproductive tract of post partum cattle (Cronin et al. 2012). The endometrial cells were isolated independently from the uteri of 33 animals and each experiment used between 3 and 12 animals on separate occasions (as enumerated subsequently). The experiments used technical replicates of at least two wells of endometrial cells for each treatment for each animal.

Uteri were transported on ice to the laboratory within $2 \mathrm{~h}$ of slaughter for immediate processing. The endometrial epithelial 
and stromal cells were isolated from the horn ipsilateral to the corpus luteum, as described previously (Fortier et al. 1988, Herath et al. 2009). Briefly, the dissected endometrial tissue from each endometrium was incubated in $25 \mathrm{ml}$ digest solution containing BSA (1 mg/ml; Sigma), collagenase II $(0.5 \mathrm{mg} / \mathrm{ml}$; Sigma) and trypsin EDTA (2.5 BAEE units/ml; Sigma) and DNAse I $(0.1 \mathrm{mg} / \mathrm{ml}$; Sigma) in Hanks Buffered Saline Solution (HBSS; Sigma) in a shaking water bath for $1 \mathrm{~h}$ at $37^{\circ} \mathrm{C}$. Following digestion, the suspension was filtered through a $40 \mu \mathrm{m}$ mesh cell strainer to remove undigested tissue. The resulting suspension was mixed with washing media containing $10 \%$ heat-inactivated foetal bovine serum (FBS, Biosera, East Sussex, UK) in HBSS before centrifugation at $700 \mathrm{~g}$ for $7 \mathrm{~min}$. The supernatant was discarded and the cell pellet was washed twice by re-suspending the cell pellet in washing media and centrifugation at $700 \mathrm{~g}$ for $7 \mathrm{~min}$. Following washing, the cell pellet was re-suspended in culture media containing $10 \%$ FBS, penicillin (50 IU $/ \mathrm{ml}$; Sigma), streptomycin $(50 \mu \mathrm{g} / \mathrm{ml}$; Sigma) and amphotericin B $(2.5 \mu \mathrm{g} / \mathrm{ml}$; Sigma) in RPMI 1640 (Sigma). The cell suspension containing epithelial cells and stromal cells was seeded at $1 \times 10^{5} \mathrm{cells} / \mathrm{ml}$ into $75 \mathrm{~cm}^{2}$ culture flasks (Greiner Bio-One, Gloucestershire, UK) and incubated at $37{ }^{\circ} \mathrm{C}$ in a humidified incubator with $5 \%$ $\mathrm{CO}_{2}$ in air. Epithelial and stromal cell populations were separated by their differential plating times, with stromal cells adhering in the initial $18 \mathrm{~h}$ of culture, after which the epithelial cell suspension was transferred to a fresh $75 \mathrm{~cm}^{2}$ culture flask and the stromal cell layer was immediately replenished with fresh media. Media changes then occurred every $48 \mathrm{~h}$.

Epithelial or stromal cells were transferred to transwell inserts or culture plates respectively following confirmation of the purity of the isolated cell populations. Cell purity of the isolated epithelial and stromal cells was $>99 \%$ as determined microscopically, based on the morphological differences between the cell types, as reported previously (Fortier et al. 1988). Endometrial cells isolated in this manner were also negative for CD45 mRNA (Herath et al. 2006). Cells were transferred from the culture flask to their final seeding environment following re-suspension in culture media, using Accutase (Sigma) to detach the cells according to the manufacturer's instructions. The impact of one or two passages and duration of culture was evaluated in preliminary experiments using epithelial and stromal cells cultured in 24-well plates, which were treated with control medium or medium containing OT + AA or LPS. There was no significant effect of one or two sub-passages or among week 1, 2 or 3 duration of culture on the ability of the cells to generate significant PGF or PGE responses to treatment compared with control (data not shown).

Initial experiments aimed at determining the TER threshold that indicated confluence of bovine endometrial epithelial cells on transwell inserts. Epithelial cells (containing both luminal and glandular epithelial cells) were seeded on Millipore transwell inserts coated with a thin coat of Matrigel (BD Biosciences, Heidelberg, Germany) diluted 1:8 with RPMI 1640, and the TER measured daily until the read-out stabilised.

To optimise the culture of polarised epithelial cells, alone or in the presence of stromal cells, this study tested a range of Matrigel coatings and transwell insert brands and the seeding densities that would result in simultaneous establishment of polarised epithelial cell and stromal cell confluence for co-culture experiments. Three Matrigel coatings were tested, where epithelial or stromal cells were seeded on a 'Thin Coat' of Matrigel diluted 1:8 in RPMI 1640, providing a non-gelled protein layer; on a 'Thin Gel' ( $0.5 \mathrm{~mm}$ gel layer) or alternatively stromal or epithelial cells were embedded within a 'Thick Gel' ( $1 \mathrm{~mm}$ gel layer). Cell proliferation on Matrigel was compared with an uncoated culture well, 'Well'. Epithelial cells were seeded at $2 \times 10^{5}$ cells $/ \mathrm{cm}^{2}$ growth area. Transwell brands tested included Millipore (Billerica, MA, USA), Greiner BioOne, BD Falcon, Corning collagen-coated (New York, NY, USA) and Nunc (Nottingham, UK), all used in conjunction with 24-well plates. Matrigel was prepared according to the manufacturer's instructions to coat the wells of 24-well plates, without transwell inserts. All transwells had $0.4 \mu \mathrm{m}$ pore size, hanging geometry except the Nunc transwell, which had $0.2 \mu \mathrm{m}$ pore size and a non-hanging geometry. All transwells were pre-coated with Matrigel diluted 1:8 in RPMI 1640, except for the Corning collagen-coated transwell insert. The cell seeding densities were tested using 24-well plates used in conjunction with Millipore transwell inserts coated with a thin coat of Matrigel. Epithelial cells were seeded in transwell inserts at 1,2 or $3 \times 10^{5}$ cells $/ \mathrm{ml}$, and stromal cells were seeded in the culture plate well at 0.5 or $1 \times 10^{5}$ cell $\mathrm{s} / \mathrm{ml}$. Confluence was evaluated using TER and microscopy for epithelial and stromal cells respectively. The TER was measured using an epithelial volt-ohm meter (EVOM ${ }^{2}$, World Precision Instruments, Hertfordshire, UK), with resistance of current across the insert membrane measured by placing electrodes in the apical and basolateral compartments. Cell-free inserts were measured to assess the blank resistance and the data expressed as unit area resistance TER $\left(\Omega \mathrm{cm}^{2}\right)$ according to the following formula:

$$
\begin{aligned}
\operatorname{TER}\left(\Omega \mathrm{cm}^{2}\right)= & (\text { sample resistance }- \text { blank resistance }) \\
& \times \text { membrane area. }
\end{aligned}
$$

Subsequent experiments using polarised epithelial cells were prepared using Millipore transwell inserts coated with Matrigel diluted 1:8 in RPMI 1640, in conjunction with 24-well plates (TPP, Helena Biosciences, Gateshead, UK). The working volumes for the inner compartment of the insert (apical compartment) and the well below (basolateral compartment) were 300 and $800 \mu \mathrm{l}$ respectively. Epithelial cells $\left(3 \times 10^{5}\right.$ cells $\left./ \mathrm{ml}\right)$ were seeded into the apical compartment on transwell inserts, with media in the well below. Polarised epithelial cells were incubated at $37^{\circ} \mathrm{C}$, with $5 \% \mathrm{CO}_{2}$ in air in a humidified incubator, with media changes occurring $24 \mathrm{~h}$ after seeding to remove unattached cells, and then every $48 \mathrm{~h}$ thereafter. Polarised epithelial cell confluence was determined by TER, which was monitored daily. For co-culture studies, stromal cells $\left(1 \times 10^{5}\right.$ cells $\left./ \mathrm{ml}\right)$ were seeded into the basolateral compartment of 24-well culture plates once epithelial cells in the transwells TER was $>1500 \Omega \mathrm{cm}^{2}$.

\section{Treatment of endometrial cell cultures}

To examine the physiological responses of endometrial cells, transwell inserts and 24-well plates were used with the cells 
seeded as i) polarised epithelial monocultures grown in the apical compartment of transwell inserts, ii) stromal monocultures seeded in the culture well below a cell-free transwell insert or iii) as co-cultures of stromal cells seeded in the culture well below a transwell insert containing polarised epithelial cells in the apical compartment. Cell cultures were treated for $24 \mathrm{~h}$ with OT (100 nM; Bachem, St Helens, UK) and/or AA (100 $\mu \mathrm{M}$; Sigma) applied to both the apical and the basolateral compartments, separated by transwell inserts. For polarised epithelial monocultures (1) and co-cultures (3), the apical and basolateral supernatants were collected and analysed separately, although the supernatants from the apical and basolateral compartments were pooled before analysis when a cell-free transwell insert was used above the stromal cell monocultures (2). All supernatants were stored at $-20^{\circ} \mathrm{C}$ for later analysis.

To examine endometrial cellular responses associated with disease, transwell inserts and 24-well culture plates were used with cells seeded as i) polarised epithelial monocultures grown in the apical compartment of transwell inserts, ii) stromal monocultures seeded in the wells of 24-well plates without a transwell insert or iii) as co-cultures of stromal cells seeded in the culture well below a transwell insert containing polarised epithelial cells in the apical compartment. Cell cultures were treated for $24 \mathrm{~h}$ with ultrapure LPS from E. coli $(0,0.001,0.01$, $0.1,1$ or $10 \mu \mathrm{g} / \mathrm{ml}$; Invivogen) added to both the apical and the basolateral compartments of epithelial cells and co-cultures, or to the well of stroma cell monocultures. To further explore vectorial secretory responses, either the apical and/or the basolateral compartment of transwell insert of polarised epithelial or co-cultures were treated with LPS $(1 \mu \mathrm{g} / \mathrm{ml})$ for $24 \mathrm{~h}$ with control media in the untreated compartment. Stromal cell monocultures were also treated with control media or LPS $(1 \mu \mathrm{g} / \mathrm{ml})$ for $24 \mathrm{~h}$. The TER was measured immediately before treatment and $24 \mathrm{~h}$ later. Supernatants were collected and stored at $-20{ }^{\circ} \mathrm{C}$.

\section{3-(4,5-Dimethylthiazol-2-yl)2-5-diphenyl-tetrazolium bromide assay}

To determine the effects of OT, AA and LPS treatment on endometrial cell proliferation or viability, the number of cells was quantified using the 3-(4,5-dimethylthiazol-2-yl)2-5diphenyl-tetrazolium bromide (MTT) assay, as described for transwell inserts (Zund et al. 1999, Skibinski et al. 2007). Briefly, each well or transwell insert compartment was incubated with MTT $(10 \mathrm{mg} / \mathrm{ml}$ MTT; Sigma) in fresh culture media for $2 \mathrm{~h}$ at $37^{\circ} \mathrm{C}$ and $5 \% \mathrm{CO}_{2}$ in air. The MTT-media solution was removed and the inserts were transferred to fresh culture plates to prevent mixing between compartments following cell lysis. Cell lysis was performed using $400 \mu \mathrm{l}$ dimethyl sulfoxide (DMSO; Sigma) per compartment or well to dissolve the formazan crystals. The optical density of DMSOformazan solution $(100 \mu \mathrm{l} /$ well) was measured in a 96 -well plate (TPP) using a plate reader (Polarstar Omega; BMG Labware, Aylesbury, UK) at $570 \mathrm{~nm}$ absorbance. The number of cells was calculated using separate standard curves for epithelial and stromal cells, and the $R^{2}$ values were 0.9178 and 0.991 for epithelial and stromal cells respectively.

\section{ELISA}

The amount of IL8 in the cell culture supernatants was determined by ELISA according to the manufacturer's instructions (Human CXCL8/IL8 DuoSet (DY208; R\&D Systems, Abingdon, UK)). The human IL8 DuoSet ELISA kit had been previously validated for measuring bovine IL8 (Rinaldi et al. 2008). The limit of detection was $6.0 \mathrm{pg} / \mathrm{ml}$, and the intra- and inter-assay coefficients of variation were 4.7 and $6.7 \%$ respectively.

\section{RIA}

The PGE and PGF content of supernatants was analysed by an established, validated RIA, as described previously (Cheng et al. 2001, Leung et al. 2001, Herath et al. 2006). Samples, PGE and PGF standards (Sigma) and titrated PGE and PGF tracers (GE Healthcare, Buckinghamshire, UK) were diluted in $0.05 \mathrm{M}$ Tris buffer (Sigma) containing $0.1 \%$ gelatin (Sigma) and $0.01 \%$ sodium azide (Sigma). The antisera were a generous gift from Prof. N L Poyser (University of Edinburgh, UK) and their lack of cross-reactivity has been reported previously (Poyser 1987). The limits of detection for PGE and PGF were 0.6 and $0.3 \mathrm{ng} / \mathrm{ml}$ respectively. The intra- and inter-assay coefficients of variation were 8.0 and $11.9 \%$ for PGE and 6.0 and $13 \%$ for PGF respectively.

\section{Isolation of bovine neutrophils for transmigration assays}

Blood samples were collected aseptically by venipuncture of the vena jugularis externa into heparinised vacutainer tubes (BD Biosciences) from healthy Holstein/Friesian cows $(n=4)$. The experiments were conducted according to the rules of the German animal welfare law and were licensed by the local authorities. This is in accordance with the International Guiding Principles for Biomedical Research involving animals. Blood was diluted with PBS (1:2), overlaid on lymphocyte separation medium LSM 1077 containing Ficoll (PAA, Cölbe, Germany). After centrifugation $\left(1000 \mathrm{~g}, 30 \mathrm{~min}\right.$ at $\left.4{ }^{\circ} \mathrm{C}\right)$, the interphase layer containing mononuclear cells (MNCs) and the separation medium was discarded. The red blood cell sediment containing granulocytes (polymorphonuclear cells, PMNs) was subjected to two consecutive hypotonic lysis steps with distilled water. Purity of viable neutrophils in the PMN population was $87 \pm 6 \%$ and contained $\sim 10 \%$ eosinophils and $<10 \%$ MNCs. The PMNs were used immediately in transmigration assays.

\section{Transmigration assays}

Transmigration assays were performed in ten-well chemotaxis chambers (NeuroProbe, Warwickshire, UK). Upper and lower wells were separated by a polycarbonate membrane $(3 \mu \mathrm{m}$ pore size; NeuroProbe). The lower well contained $300 \mu$ l of the chemotaxis solution, described subsequently, underlaid with $125 \mu \mathrm{l}$ isotonic percoll. The upper well contained $1.5 \times 10^{6}$ $\mathrm{PMN} /$ well. Chambers were incubated for $2 \mathrm{~h}$ at $37{ }^{\circ} \mathrm{C}, 5 \% \mathrm{CO}_{2}$ in air. Following incubation, the complete content of upper and lower wells was harvested separately and cells were quantified 
flow cytometrically as described previously (Pechhold et al. 1994, Zerbe et al. 2003). The migration rates of neutrophils from different animals to recombinant IL8 $(100 \mathrm{ng} / \mathrm{ml})$ were set to $100 \%$ and migration to endometrial or stromal cell supernatants was expressed as migration relative to IL8. The morphology of migrated PMN was measured using flow cytometry, recording the mean forward (apparent size) and side scatter (complexity) values (FCS Express; De Novo Software, Los Angeles, CA, USA).

Chemotaxis ( $n=1$ blood donor) to the following treatments was explored: endometrial cell culture media; $100 \mathrm{ng} / \mathrm{ml}$ rhlL8 (PeproTech, Rocky Hill, NJ, USA) endometrial culture media containing $0.1,1,5$ or $10 \mu \mathrm{g} / \mathrm{ml}$ LPS; endometrial supernatants from polarised epithelial monoculture; stromal monoculture or co-cultured cells ( $n=3$ uteri) treated with $\operatorname{LPS}(0,0.1,1,5$ or $10 \mu \mathrm{g} / \mathrm{ml} \mathrm{LPS})$. Culture media and cell supernatants were diluted $1: 3$ to reduce the FBS content to $2.5 \%$. Migration to 0 , $5,10,25,50,75,100,150$ or $200 \mathrm{ng} / \mathrm{ml}$ rhlL8 or recombinant bovine IL8 (Thermofisher Scientific, Hertfordshire, UK) was compared.

Inhibition of neutrophil migration to endometrial cell supernatants treated with control media or $1 \mu \mathrm{g} / \mathrm{ml}$ LPS was tested using mouse anti-ovine IL8 (Millipore). Endometrial supernatants (cells isolated from $n=3$ uteri), $7.5 \mathrm{ng} / \mathrm{ml} \mathrm{rblL8}$ and endometrial culture media were incubated with anti-IL8 antibody $(1 \mu \mathrm{g} / \mathrm{ml})$ for $30 \mathrm{~min}$ on ice at $4{ }^{\circ} \mathrm{C}$ before performing the chemotaxis assay ( $n=3$ blood donors). Culture media and cell supernatants were diluted $1: 7$ to reduce the FBS content to $1.25 \%$ before performing the assay or addition of anti-IL8 antibody.

\section{Paraffin embedding of polarised epithelial cells}

Polarised epithelial cell monocultures on transwell inserts were grown to confluence (TER $>1800 \Omega \mathrm{cm}^{2}$ ) before the transwell membrane was removed from the plastic housing using a cork borer (Fisher, Hertfordshire, UK). The membranes were rinsed twice in Dulbecco's PBS (DPBS, Sigma) at $37^{\circ} \mathrm{C}$ for $5 \mathrm{~min}$ and immersed in $2 \%$ paraformaldehyde (PFA; Sigma) at $37^{\circ} \mathrm{C}$ for $5 \mathrm{~min}$. The membranes were then washed three times in DPBS for $5 \mathrm{~min}$ and stored in DPBS plus $0.2 \%$ sodium azide at $4{ }^{\circ} \mathrm{C}$. The transwell membranes were dehydrated through a graded series of alcohol (70, 90, 100, 100, and 100 industrial methylated spirit (IMS) for 30 min each, 1:1 mixture of $100 \%$ IMS: $100 \%$ xylene for $45 \mathrm{~min}, 100 \%$ xylene overnight and $100 \%$ xylene for $30 \mathrm{~min}$ ), before embedding in paraffin (Paraplast, Taab, Berkshire, UK). Transwell membranes embedded in paraffin were cut into $6 \mu \mathrm{m}$ transverse sections using a microtome (Microtome HM360; Richard Allen Scientific, Fisher) and mounted on polylysine-coated slides (VWR, Leicestershire, UK).

\section{Staining and imaging polarised epithelial cells}

Tissue sections were de-waxed and rehydrated in three changes of $100 \%$ xylene for $5 \mathrm{~min}$ and immersion in 100, 90, $70 \%$ ethanol and water for $2 \mathrm{~min}$. The sections were stained with haematoxylin (Merck) for 6 min, washed in tap water for 5 min and transferred to $0.5 \%$ eosin (Merck) for $6 \mathrm{~min}$. The slides were then rinsed in tap water and dehydrated through 70, 90 and $100 \%$ ethanol for $30 \mathrm{~s}$ each. Finally, slides were immersed in $100 \%$ xylene for 5 min each and mounted with dibutyl phthalate in xylene neutral mounting media (DPX; Taab). Slides were imaged using an upright microscope (Axio Imager M1; Zeiss, Jena, Germany) fitted with an AxioCam colour high-resolution camera in conjunction with Axiovision software (Zeiss).

For immunocytochemistry (ICC), rehydrated slides were incubated in a pressure cooker at boiling point in sodium citrate, $\mathrm{pH}$ 6, for $3 \mathrm{~min}$. Slides were cooled in running tap water for 10 min before being washed in Tris-buffered saline (TBS; Sigma) containing $0.025 \%$ Triton X-100 (Sigma) for $5 \mathrm{~min} /$ wash. Slides were blocked in $5 \%$ donkey serum (Jackson ImmunoResearch, Suffolk, UK) diluted in TBS plus 1\% BSA for $2 \mathrm{~h}$ at room temperature. Slides were incubated with primary antibodies rabbit anti-cytokeratin (Abcam, Cambridgeshire, UK) and mouse anti-ZO1 (Invitrogen) diluted 1:100 in TBS plus $1 \%$ BSA at $4{ }^{\circ} \mathrm{C}$ overnight. Slides were washed three times in TBS plus $1 \%$ BSA for $5 \mathrm{~min} /$ wash before incubating in secondary antibodies, donkey anti-mouse 488 and donkey anti-rabbit 555 (Molecular Probes, Invitrogen) in the dark for $1.5 \mathrm{~h}$ at room temperature. Slides were washed three times in TBS plus $1 \%$ BSA for $5 \mathrm{~min} /$ wash and mounted using DAPI/Vectashield (H-1200; Vector Labs, Inc., Peterborough, UK). Slides were imaged using an upright microscope with fluorescence (Axio Imager M1) fitted with an AxioCam MRm camera (Zeiss) in conjunction with Axiovision software (Zeiss).

\section{Statistical analysis}

Data represent the arithmetic mean \pm S.E.M. calculated by hand. Data were analysed using PASW statistics (v.18; SPSS). The animal was the statistical unit. Prostaglandin and IL8 data are expressed as total amount/compartment, calculated by multiplying sample concentration by sample volume, to account for volume differences between the apical and the basolateral compartments. Data were analysed using log-transformed values of PGE, PGF and IL8 for generalised estimating equations with Bonferroni post hoc test, to compare the effect of cell treatment, compartment and culture condition. Neutrophil migration, epithelial TER and endometrial cell numbers were analysed using ANOVA and Bonferroni post hoc test. Changes in migrated neutrophil cell size and complexity were analysed using paired T-test. A probability value of $P<0.05$ was taken as significant.

\section{Supplementary data}

This is linked to the online version of the paper at http://dx.doi. org/10.1530/REP-12-0253.

\section{Declaration of interest}

The authors declare that there is no conflict of interest that could be perceived as prejudicing the impartiality of the research reported. 


\section{Funding}

S B MacKintosh (née Price) was funded by a doctoral BBSRC CASE doctoral training grant (grant: BB/D526761/1). BBSRC and Pfizer provided financial support to this work.

\section{Acknowledgements}

The authors thank T Hopcroft and E Shervill (Royal Veterinary College) and Dr J Bromfield (Swansea University) for advice. Detailed advice and guidance for the statistical analysis was kindly provided by Dr R Chang (Royal Veterinary College).

\section{References}

Archbald LF, Schultz RH, Fahning ML, Kurtz HJ \& Zemjanis R 1972 A sequential histological study of the post-partum bovine uterus. Journal of Reproduction and Fertility 29 133-136. (doi:10.1530/jrf.0.0290133)

Arnold JT, Kaufman DG, Seppala M \& Lessey BA 2001 Endometrial stromal cells regulate epithelial cell growth in vitro: a new co-culture model. Human Reproduction 16 836-845. (doi:10.1093/humrep/16.5.836)

Asselin E, Goff AK, Bergeron H \& Fortier MA 1996 Influence of sex steroids on the production of prostaglandins $F_{2 \alpha}$ and $E_{2}$ and response to oxytocin in cultured epithelial and stromal cells of the bovine endometrium. Biology of Reproduction 54 371-379. (doi:10.1095/biolreprod54.2.371)

Balda MS, Fallon MB, Van Itallie CM \& Anderson JM 1992 Structure, regulation, and pathophysiology of tight junctions in the gastrointestinal tract. Yale Journal of Biology and Medicine 65 725-735 (discussion 737-740).

Banu SK, Arosh JA, Chapdelaine P \& Fortier MA 2003 Molecular cloning and spatio-temporal expression of the prostaglandin transporter: a basis for the action of prostaglandins in the bovine reproductive system. PNAS 100 11747-11752. (doi:10.1073/pnas.1833330100)

Banu SK, Arosh JA, Chapdelaine P \& Fortier MA 2005 Expression of prostaglandin transporter in the bovine uterus and fetal membranes during pregnancy. Biology of Reproduction 73 230-236. (doi:10.1095/ biolreprod.105.039925)

Bowen JA, Newton GR, Weise DW, Bazer FW \& Burghardt RC 1996 Characterization of a polarized porcine uterine epithelial model system. Biology of Reproduction 55 613-619. (doi:10.1095/biolreprod55.3.613)

Braileanu GT, Hu J \& Mirando MA 2000 Directional secretion of prostaglandin $F(2 \alpha)$ by polarized luminal epithelial cells from pig endometrium. Prostaglandins and Other Lipid Mediators 60 167-174. (doi:10.1016/S0090-6980(99)00061-1)

Bridger PS, Menge C, Leiser R, Tinneberg HR \& Pfarrer CD 2007 Bovine caruncular epithelial cell line (BCEC-1) isolated from the placenta forms a functional epithelial barrier in a polarised cell culture model. Placenta 28 1110-1117. (doi:10.1016/j.placenta.2007.07.002)

Caswell JL, Middleton DM \& Gordon JR 1999 Production and functional characterization of recombinant bovine interleukin-8 as a specific neutrophil activator and chemoattractant. Veterinary Immunology and Immunopathology 67 327-340. (doi:10.1016/S0165-2427(99)00007-0)

Chapwanya A, Meade KG, Doherty ML, Callanan JJ, Mee JF \& O'Farrelly C 2009 Histopathological and molecular evaluation of Holstein-Friesian cows postpartum: toward an improved understanding of uterine innate immunity. Theriogenology 71 1396-1407. (doi:10.1016/j.theriogenology.2009.01.006)

Cheng Z, Robinson RS, Pushpakumara PG, Mansbridge RJ \& Wathes DC 2001 Effect of dietary polyunsaturated fatty acids on uterine prostaglandin synthesis in the cow. Journal of Endocrinology 171 463-473. (doi:10.1677/joe.0.1710463)

Chow AW, Liang JF, Wong JS, Fu Y, Tang NL \& Ko WH 2010 Polarized secretion of interleukin (IL)-6 and IL-8 by human airway epithelia 16 HBE14o- cells in response to cationic polypeptide challenge. PLOS ONE 5 e12091. (doi:10.1371/journal.pone.0012091)
Cobb SP \& Watson ED 1995 Immunohistochemical study of immune cells in the bovine endometrium at different stages of the oestrous cycle. Research in Veterinary Science 59 238-241. (doi:10.1016/00345288(95)90010-1)

Cooke PS, Buchanan DL, Young P, Setiawan T, Brody J, Korach KS, Taylor J, Lubahn DB \& Cunha GR 1997 Stromal estrogen receptors mediate mitogenic effects of estradiol on uterine epithelium. PNAS 94 6535-6540. (doi:10.1073/pnas.94.12.6535)

Cronin JG, Turner ML, Goetze L, Bryant CE \& Sheldon IM 2012 Toll-like receptor 4 and MYD88-dependent signaling mechanisms of the innate immune system are essential for the response to lipopolysaccharide by epithelial and stromal cells of the bovine endometrium. Biology of Reproduction 86 51. (doi:10.1095/biolreprod.111.092718)

Davies D, Meade KG, Herath S, Eckersall PD, Gonzalez D, White JO, Conlan RS, O'Farrelly C \& Sheldon IM 2008 Toll-like receptor and antimicrobial peptide expression in the bovine endometrium. Reproductive Biology and Endocrinology 6 53. (doi:10.1186/1477-7827-6-53)

Donjacour AA \& Cunha GR 1991 Stromal regulation of epithelial function. Cancer Treatment and Research 53 335-364.

Ellinwood WE, Nett TM \& Niswender GD 1979 Maintenance of the corpus luteum of early pregnancy in the ewe. II. Prostaglandin secretion by the endometrium in vitro and in vivo. Biology of Reproduction 21 845-856. (doi:10.1095/biolreprod21.4.845)

Fahey JV, Schaefer TM, Channon JY \& Wira CR 2005 Secretion of cytokines and chemokines by polarized human epithelial cells from the female reproductive tract. Human Reproduction 20 1439-1446. (doi:10.1093/ humrep/deh806)

Fischer C, Drillich M, Odau S, Heuwieser W, Einspanier R \& Gabler C 2010 Selected pro-inflammatory factor transcripts in bovine endometrial epithelial cells are regulated during the oestrous cycle and elevated in case of subclinical or clinical endometritis. Reproduction, Fertility, and Development 22 818-829. (doi:10.1071/RD09120)

Fortier MA, Guilbault LA \& Grasso F 1988 Specific properties of epithelial and stromal cells from the endometrium of cows. Journal of Reproduction and Fertility 83 239-248. (doi:10.1530/jrf.0.0830239)

Galligan CL \& Coomber BL 2000 Effects of human IL-8 isoforms on bovine neutrophil function in vitro. Veterinary Immunology and Immunopathology 74 71-85. (doi:10.1016/S0165-2427(00)00162-8)

Giepmans BN \& van ljzendoorn SC 2009 Epithelial cell-cell junctions and plasma membrane domains. Biochimica et Biophysica Acta $\mathbf{1 7 8 8}$ 820-831. (doi:10.1016/j.bbamem.2008.07.015)

Glasser SR, Julian J, Decker GL, Tang JP \& Carson DD 1988 Development of morphological and functional polarity in primary cultures of immature rat uterine epithelial cells. Journal of Cell Biology 107 2409-2423. (doi:10.1083/jcb.107.6.2409)

Goff AK 2004 Steroid hormone modulation of prostaglandin secretion in the ruminant endometrium during the estrous cycle. Biology of Reproduction 71 11-16. (doi:10.1095/biolreprod.103.025890)

Grant KS \& Wira CR 2003 Effect of mouse uterine stromal cells on epithelial cell transepithelial resistance (TER) and TNF $\alpha$ and TGF $\beta$ release in culture. Biology of Reproduction 69 1091-1098. (doi:10.1095/biolreprod.103.015495)

Grant-Tschudy KS \& Wira CR 2005a Effect of oestradiol on mouse uterine epithelial cell tumour necrosis factor- $\alpha$ release is mediated through uterine stromal cells. Immunology 115 99-107. (doi:10.1111/j.13652567.2005.02134.x)

Grant-Tschudy KS \& Wira CR 2005b Hepatocyte growth factor regulation of uterine epithelial cell transepithelial resistance and tumor necrosis factor $\alpha$ release in culture. Biology of Reproduction 72 814-821. (doi:10.1095/ biolreprod.104.035618)

Herath S, Fischer DP, Werling D, Williams EJ, Lilly ST, Dobson H, Bryant CE \& Sheldon IM 2006 Expression and function of Toll-like receptor 4 in the endometrial cells of the uterus. Endocrinology $147 \quad 562-570$. (doi:10.1210/en.2005-1113)

Herath S, Lilly ST, Fischer DP, Williams EJ, Dobson H, Bryant CE \& Sheldon IM 2009 Bacterial lipopolysaccharide induces an endocrine switch from prostaglandin $F_{2 \alpha}$ to prostaglandin $E_{2}$ in bovine endometrium. Endocrinology 150 1912-1920. (doi:10.1210/en.2008-1379)

Horn S, Bathgate R, Lioutas C, Bracken K \& Ivell R 1998 Bovine endometrial epithelial cells as a model system to study oxytocin receptor regulation. Human Reproduction Update 4 605-614. (doi:10.1093/ humupd/4.5.605) 
Ireland JJ, Murphee RL \& Coulson PB 1980 Accuracy of predicting stages of bovine estrous cycle by gross appearance of the corpus luteum. Journal of Dairy Science 63 155-160. (doi:10.3168/jds.S0022-0302(80)82901-8)

Itoh M, Furuse M, Morita K, Kubota K, Saitou M \& Tsukita S 1999 Direct binding of three tight junction-associated MAGUKs, ZO-1, ZO-2, and ZO-3, with the COOH termini of claudins. Journal of Cell Biology 147 1351-1363. (doi:10.1083/jcb.147.6.1351)

Jacobs AL, Decker GL, Glasser SR, Julian J \& Carson DD 1990 Vectorial secretion of prostaglandins by polarized rodent uterine epithelial cells. Endocrinology 126 2125-2136. (doi:10.1210/endo-126-4-2125)

Kannaki TR, Shanmugam M \& Verma PC 2011 Toll-like receptors and their role in animal reproduction. Animal Reproduction Science 125 1-12. (doi:10.1016/j.anireprosci.2011.03.008)

Kanoh S, Tanabe T \& Rubin BK 2011 Dapsone inhibits IL-8 secretion from human bronchial epithelial cells stimulated with LPS and resolves airway inflammation in the ferret. Chest 140 980-990. (doi:10.1378/ chest.10-2908)

Kleinman HK \& Martin GR 2005 Matrigel: basement membrane matrix with biological activity. Seminars in Cancer Biology 15 378-386. (doi:10.1016/j.semcancer.2005.05.004)

Kubota Y, Kleinman HK, Martin GR \& Lawley TJ 1988 Role of laminin and basement membrane in the morphological differentiation of human endothelial cells into capillary-like structures. Journal of Cell Biology 107 1589-1598. (doi:10.1083/jcb.107.4.1589)

Lacroix-Pepin N, Danyod G, Krishnaswamy N, Mondal S, Rong PM, Chapdelaine P \& Fortier MA 2011 The multidrug resistance-associated protein 4 (MRP4) appears as a functional carrier of prostaglandins regulated by oxytocin in the bovine endometrium. Endocrinology 152 4993-5004. (doi:10.1210/en.2011-1406)

Lee J, McCracken JA, Banu SK, Rodriguez R, Nithy TK \& Arosh JA 2010 Transport of prostaglandin $F(2 \alpha)$ pulses from the uterus to the ovary at the time of luteolysis in ruminants is regulated by prostaglandin transportermediated mechanisms. Endocrinology 151 3326-3335. (doi:10.1210/ en.2009-0948)

Leung ST, Cheng Z, Sheldrick EL, Derecka K, Flint AP \& Wathes DC 2001 The effects of lipopolysaccharide and interleukins- $1 \alpha,-2$ and -6 on oxytocin receptor expression and prostaglandin production in bovine endometrium. Journal of Endocrinology 168 497-508. (doi:10.1677/joe. 0.1680497)

Mahfoudi A, Nicollier M, Propper AY, Coumes-Marquet S \& Adessi GL 1991 Establishment of endometrial glandular epithelial cell subculture in a serum-free, hormonally defined medium, on a basement membrane matrix. Biology of the Cell 71 255-265. (doi:10.1016/02484900(91)90268-R)

Mateus L, Lopes da Costa L, Diniz P \& Ziecik AJ 2003 Relationship between endotoxin and prostaglandin (PGE2 and PGFM) concentrations and ovarian function in dairy cows with puerperal endometritis. Animal Reproduction Science 76 143-154. (doi:10.1016/S0378-4320(02) 00248-8)

Matter K, Aijaz S, Tsapara A \& Balda MS 2005 Mammalian tight junctions in the regulation of epithelial differentiation and proliferation. Current Opinions in Cell Biology 17 453-458. (doi:10.1016/j.ceb.2005.08.003)

Meyer HH, Mittermeier T \& Schams D 1988 Dynamics of oxytocin, estrogen and progestin receptors in the bovine endometrium during the estrous cycle. Acta Endocrinologica 118 96-104. (doi:10.1530/acta.0. 1180096)

Niswender GD, Juengel JL, Silva PJ, Rollyson MK \& McIntush EW 2000 Mechanisms controlling the function and life span of the corpus luteum. Physiological Reviews 80 1-29.

Pechhold K, Pohl T \& Kabelitz D 1994 Rapid quantification of lymphocyte subsets in heterogeneous cell populations by flow cytometry. Cytometry 16 152-159. (doi:10.1002/cyto.990160209)

Pierro E, Minici F, Alesiani O, Miceli F, Proto C, Screpanti I, Mancuso S \& Lanzone A 2001 Stromal-epithelial interactions modulate estrogen responsiveness in normal human endometrium. Biology of Reproduction 64 831-838. (doi:10.1095/biolreprod64.3.831)

Poyser NL 1987 Effects of various factors on prostaglandin synthesis by the guinea-pig uterus. Journal of Reproduction and Fertility 81 269-276. (doi:10.1530/jrf.0.0810269)

Rinaldi M, Ceciliani F, Lecchi C, Moroni P \& Bannerman DD 2008 Differential effects of $\alpha 1$-acid glycoprotein on bovine neutrophil respiratory burst activity and IL-8 production. Veterinary Immunology and Immunopathology 126 199-210. (doi:10.1016/j.vetimm.2008. 07.001)

Schatz F, Gordon RE, Laufer N \& Gurpide E 1990 Culture of human endometrial cells under polarizing conditions. Differentiation $\mathbf{4 2}$ 184-190. (doi:10.1111/j.1432-0436.1990.tb00760.x)

Schuster VL 1998 Molecular mechanisms of prostaglandin transport. Annual Reviews of Physiology 60 221-242. (doi:10.1146/annurev. physiol.60.1.221)

Sheldon IM, Cronin J, Goetze L, Donofrio G \& Schuberth HJ 2009 Defining postpartum uterine disease and the mechanisms of infection and immunity in the female reproductive tract in cattle. Biology of Reproduction 81 1025-1032. (doi:10.1095/biolreprod.109.077370)

Sheldon IM, Rycroft AN, Dogan B, Craven M, Bromfield JJ, Chandler A, Roberts MH, Price SB, Gilbert RO \& Simpson KW 2010 Specific strains of Escherichia coli are pathogenic for the endometrium of cattle and cause pelvic inflammatory disease in cattle and mice. PLOS ONE 5 1-13. (doi:10.1371/journal.pone.0009192)

Shen L, Fahey JV, Hussey SB, Asin SN, Wira CR \& Fanger MW 2004 Synergy between IL-8 and GM-CSF in reproductive tract epithelial cell secretions promotes enhanced neutrophil chemotaxis. Cellular Immunology 230 23-32. (doi:10.1016/j.cellimm.2004.08.004)

Skibinski G, Elborn JS \& Ennis M 2007 Bronchial epithelial cell growth regulation in fibroblast cocultures: the role of hepatocyte growth factor. American Journal of Physiology. Lung Cellular and Molecular Physiology 293 L69-L76. (doi:10.1152/ajplung.00299.2006)

Soboll G, Shen L \& Wira CR 2006 Expression of Toll-like receptors (TLR) and responsiveness to TLR agonists by polarized mouse uterine epithelial cells in culture. Biology of Reproduction 75 131-139. (doi:10.1095/ biolreprod.106.050690)

Takeuchi O \& Akira S 2010 Pattern recognition receptors and inflammation. Cell 140 805-820. (doi:10.1016/j.cell.2010.01.022)

Thibodeaux JK, Roussel JD, Menezo Y, Godke RA \& Goodeaux LL 1991 A method for the in vitro cell culture of superficial bovine uterine endometrial epithelium. Journal of Tissue Culture Methods $\mathbf{1 3}$ 247-252. (doi:10.1007/BF02388256)

Tithof PK, Roberts MP, Guan W, Elgayyar M \& Godkin JD 2007 Distinct phospholipase $\mathrm{A} 2$ enzymes regulate prostaglandin $\mathrm{E}_{2}$ and $\mathrm{F}_{2 \alpha}$ production by bovine endometrial epithelial cells. Reproductive Biology and Endocrinology 5 16. (doi:10.1186/1477-7827-5-16)

Tsukita S, Furuse M \& Itoh M 2001 Multifunctional strands in tight junctions. Nature Reviews. Molecular Cell Biology 2 285-293. (doi:10.1038/35067088)

Ulbrich SE, Meyer SU, Zitta K, Hiendleder S, Sinowatz F, Bauersachs S, Buttner M, Frohlich T, Arnold GJ, Reichenbach HD et al. 2011 Bovine endometrial metallopeptidases MMP14 and MMP2 and the metallopeptidase inhibitor TIMP2 participate in maternal preparation of pregnancy. Molecular and Cellular Endocrinology $332 \quad 48-57$. (doi:10.1016/j.mce.2010.09.009)

Waclawik A, Blitek A \& Ziecik AJ 2010 Oxytocin and tumor necrosis factor $\alpha$ stimulate expression of prostaglandin $E_{2}$ synthase and secretion of prostaglandin $E_{2}$ by luminal epithelial cells of the porcine endometrium during early pregnancy. Reproduction 140 613-622. (doi:10.1530/REP10-0092)

Wagner WC \& Hansel W 1969 Reproductive physiology of the post partum cow. I. Clinical and histological findings. Journal of Reproduction and Fertility 18 493-500. (doi:10.1530/jrf.0.0180493)

Williams EJ, Fischer DP, Pfeiffer DU, England GC, Noakes DE, Dobson H \& Sheldon IM 2005 Clinical evaluation of postpartum vaginal mucus reflects uterine bacterial infection and the immune response in cattle. Theriogenology 63 102-117. (doi:10.1016/j.theriogenology.2004. 03.017)

Wira CR, Grant-Tschudy KS \& Crane-Godreau MA 2005 Epithelial cells in the female reproductive tract: a central role as sentinels of immune protection. American Journal of Reproductive Immunology 53 65-76. (doi:10.1111/j.1600-0897.2004.00248.x)

Zerbe H, Schuberth HJ, Engelke F, Frank J, Klug E \& Leibold W 2003 Development and comparison of in vivo and in vitro models for endometritis in cows and mares. Theriogenology 60 209-223. (doi:10.1016/S0093-691X(02)01376-6) 
Zhang YL \& Davis DL 2000 Morphology of luminal and glandular epithelial cells from pig endometrium grown on plastic or extracellular matrices. Journal of Animal Science 78 131-138.

Zhu L \& Pollard JW 2007 Estradiol-17 $\beta$ regulates mouse uterine epithelial cell proliferation through insulin-like growth factor 1 signaling. PNAS 104 15847-15851. (doi:10.1073/pnas.0705749104)

Zund G, Ye Q, Hoerstrup SP, Schoeberlein A, Schmid AC, Grunenfelder J, Vogt P \& Turina M 1999 Tissue engineering in cardiovascular surgery: MTT, a rapid and reliable quantitative method to assess the optimal human cell seeding on polymeric meshes. European Journal of Cardiothoracic Surgery 15 519-524. (doi:10.1016/S1010-7940(99) 00068-8)

Received 3 July 2012

First decision 31 August 2012

Accepted 31 October 2012 